\title{
NATIONAL DEFENCE EXPENDITURE AND ITS IMPLICATIONS ON ECONOMIC DEVELOPMENT IN NIGERIA
}

\author{
Raymond Minini ${ }^{1}$ and Ibyingibo Selem-Amachree ${ }^{2}$ \\ Department of General Studies, School of foundation and General Studies, Captain Elechi \\ Amadi Polytechnic, Rumuola, Port Harcourt \\ ${ }^{1}$ Email: raymondminini@yahoo.com \\ 2Email: goodmother2007@yahoo.com
}

Cite this article:

Raymond M., Ibyingibo S. (2021), National Defence Expenditure and Its Implications on Economic Development in Nigeria. African Journal of Economics and Sustainable Development 4(1), 17-31. DOI: 10.52589/AJESD4IWKVNSI.

\section{Manuscript History}

Received: 10 April 2021

Accepted: 29 April 2021

Published: 7 May 2021

Copyright $\odot 2020$ The Author(s). This is an Open Access article distributed under the terms of Creative Commons AttributionNonCommercial-NoDerivatives 4.0 International (CC BY-NC-ND 4.0 ), which permits anyone to share, use, reproduce and redistribute in any medium, provided the original author and source are credited.
ABSTRACT: The issue of security is presently a critical challenge for the Nigeria State: biggest democracy in Africa as reports of killings are plastered on a daily basis on both print and social media. This is unpalatable for a developing country like Nigeria that has its eyes set on improving the lot of its citizens and becoming a force to reckon with in the global economy. It is on this backdrop that this study set sail to examine the association between national defence expenditure and economic development in Nigeria. The study adopted Ex-post facto research design as the variables- Misery Index, CDEX and RDEX: cannot be manipulated as they are annual time series data sourced from the World Development Indicator and the Central Bank of Nigeria annual report from a period of 38 years covering from 1981 to 2018, which were in turn analyzed using the error correction model (ECM) method of estimation. The result of the Johansen cointegration test revealed that government capital spending on defence, recurrent spending on defence, foreign direct investment and misery index have common trends in the long run. The outcome of the normalized cointegration disclosed a negative and significant relationship between government capital spending on defence and misery index, while a positive and significant long run relationship exists between government recurrent spending on defence and misery index. The short run analysis pointed to a positive and significant relationship between previous year's misery index and current year's misery index. The study thus recommended that government defence spending be reassessed to make it development oriented and proper monitoring of defence spending be carried out.

KEYWORDS: National Defence Expenditure, Misery Index, Economic Development 


\section{INTRODUCTION}

Everyone deserves to live in a society as secure as can be reasonably achieved. No one wants to feel insecure. The foundational element of the social contract between people and government is security. National security then must reasonably be one of the central concerns of both government and opposition. It is therefore very important or necessary that national security is not left with politicians only, Barton (2019).

We are aware that millions of lives have been lost or driven away from their homes. The consequences will be reduction in employment and increase in inflation.

Lamentably, Nigeria is, today tormented with social issues, spates of insecurity, widespread poverty, corruption, poor health facilities, unfavorable balance of trade, ethnic and religious clashes, crime, and bad governance and all these imply that we are uncertain as far as human prosperity is concerned. In this situation, advancement is slippery like a delusion (Oshio, 2009).

As indicated by Todaro and Smith (2011), since the mid-1970s, security spending has been on the ascent, such spending in the Middle East and North Africa arrived at the midpoint of yearly increment of 22\%. In 1995, aggregate security spending by developing nations added up to $\$ 1.54$ billion representing $19.3 \%$ of global aggregate security spending, while cost on national security rose to $\$ 4.76$ billion, corresponding likewise for $22.4 \%$ of world total spending on security. The ascent in the expense of security on the planet, in general, is because of its significance in the path to development. The different developmental goals of Nigeria have been written in a plethora of vision statements; for example, the Vision 2020, NEEDS, MDGs, and so forth. These dreams, that once gave the individuals trust, are slowly turning into an illusion. As per Otto and Ukpere (2012), the Nigerian culture is getting increasingly shaky, more individuals are getting into social vices and they are getting progressively heartless, urgent and refined. The Nigeria of today, particularly since the coming of the preceding and present administration has seen heightened ethnic and tribal tension, new type of crime in the form kidnapping for ransom, militancy, Boko Haram bombings, farmers'/herdsmen clashes, politically motivated killings, rape among others, which have influenced the Nigerian economy adversely.

The effect of insecurity is very clear as it presents itself in the destruction of available infrastructures needed for industrial growth and economic development of the country. With the huge expenditure of government resources spent on tackling the menace of insecurity and the attendant destruction of existing infrastructure, one can assume that the challenges that insecurity posed to economic development are enormous. According to Joseph (2011), national security is therefore a precondition for economic and social improvement as much as economic and social improvement is a prerequisite for national security. A few specialists, for example, Adams (2009), and Beijer (2010), said that there is a trade-off between national security and development. This suggests that development suffers as the cost of security expands. Beijer (2010) opined that enhancing security in a country results in the diversion of funds meant for investment that can spur economic growth.

The above view has been contradicted by Claudia (2010). He said the expense on security may influence development, however just in the short run. Over the long run, security propels economic growth and development. Claudia (2010) included that economic and social development cannot be attained without national security. Both foreign and domestic investors 
are moved to invest their funds in an economy with a favorable security climate or ambiance and guaranteed for life and property. The normal rates of return cannot be gathered or recovered if there is instability. Likewise, government developmental activities cannot thrive in an atmosphere characterized by insecurity, thus stressing the premium placed on security (Yero, 2010; Zingel, 2010).

This work, in this manner, endeavors to evaluate the effect of national defence expenditure on economic development in Nigeria.

\section{LITERATURE REVIEW}

\section{Review of Conceptual Issues}

\section{National Security}

According to Mesjaz (2014), the English word, "security" was derived from the Latin word "Securus"; "se" means without and "curus" means "uneasiness". In other words, security means liberation from uneasiness or a peaceful situation without any risks or threats, to feel safe, to be protected.

To the ordinary man/woman, security means safety or protection from harm and danger. Security is very important because as Zabach (2011) rightly observes, "unless one can be assured of his physical security, everything else will be meaningless. Imobighe (2001) also adds that without security individuals within a state will find it difficult to engage in productive activities. In the same vein, the state will encounter difficulty in harnessing its human development and the promotion of the general well-being of the people.

According to Onovo (2009), every human being is always conscious of his or her security at any given time, and at all places, and that is why every government worth its salt all over the world makes security of lives and property within its territorial area of jurisdiction a priority agenda, just as it makes the survival, continuity, defense, and security of the state a primary goal.

According to Bello (2017), the term national security lacks a specific definition but has been described as the concern of the government about the stability and safety of a state. This is in line with Nwohie (2011) quoting Ex-president Olusegun Obasanjo that "the primary objectives of national security shall be to strengthen the federal republic of Nigeria, to advance her interests and objectives, to contain instability, control crime, eliminate corruption, enhance genuine development, progress, and growth, improve the welfare and well-being and quality of life of every citizen.

\section{Economic Development}

Economic development has been a victim of definitional pluralism. It can be viewed, for instance, as economic growth. That is the achievement of yearly increases in both the total and per capita output of goods and services (Wilson, 2017) citing Akpakpan (1987). In other words, any country that was able to achieve on a sustained basis an annual increase in its Gross National Product at the rate of between 5 and 7 percent would be described as developing. 
It can also be viewed in terms of a country's level of industrialization. For instance, if the share of industrial output in total domestic output was rising, then that country is said to be developing.

Currently, most economists and social scientists have conceived development as a multidimensional phenomenon having economic, social, political, technological and many other dimensions. It is also very important in the discussion of the quality of life of people today to include environmental issues such as pollution, environmental degradation and not just growth in per capita income, because of the externality effect of production and consumption.

According to Umo (2007), the production and consumption activities most times result in environmental damage in the form of pollution, warming of the environment and so on.

In other words, there is a need to protect the environment to avoid the persistence of poverty, unemployment inequality and health hazards because they are directly connected to the mismanagement of the environment. Hence, this paper will adopt with little addition, the definition of Akpakpan (1987 and 2011) as cited by Wilson (2017). That is, development is the process of improvement in the various aspects of the life of the society, usually seen in the occurrence of desirable changes such as;

i. an increase in the capacity of the society to produce and distribute needed goods and services.

ii. a reduction in the level of unemployment; that is, a reduction in the proportion of the population living below the poverty line;

iii. a reduction in the level of economic and social inequality;

v. an increase in real output of goods and services, that is, economic growth;

vi. a rise in the levels of social and political consciousness and political participation;

vii. an improvement in the quality of services;

viii. an improvement in the quality of life as measured by access to clean and safe water, adequate health services and decent accommodation;

ix. a reduction in pollution and or environmental degradation.

\section{Misery Index}

The misery index is an indicator, created by an economist Arthur Okun, that is used to determine how economically well off the citizens of a country are. It is the sum of the unemployment and underemployment rate and the inflation rate of a particular period.

These factors are important because they pose economic and social costs to the average income earner. Any increase in the misery index is triggered by an increase in either of the variables and signifies economic discomfort and negative consumer sentiment. If this movement persists, consumers will be hit hard. There will be dwindling purchasing power, the poor will become poorer, declining economic activity and reduced consumption. In the end, the citizen will be left with high uncertainty and low morale. Halton (2019). 


\section{Review of Theoretical Literature}

\section{The Theory of Increasing State Activity}

Wagner (1863) opined that causality or causal relationship exists between the growth of a nation and the growth of public spending. The theory states that there are inherent tendencies for the activities of government to grow intensively and extensively. Wagner (1863) observed a tendency for government spending to rise proportionately or directly with the level of industrial output in a country, hence the call for increased allowance of social consideration in the conduct of industrial activities as such is capable of causing an increasing expansion of the public sector. The increased tendency is attributed to social problems, population growth, rise in prices and national income, and urbanization as more social infrastructure is needed to cater for the consequences of the above-mentioned increase in social variables. Wagner's theory has been criticized because it failed to take into consideration the influence of war on the composition of government spending Peacock (1961).

\section{Peacock-Wiseman's Theory}

Based on their critical examination of the pattern of government spending in the United Kingdom from 1890 to 1955, Peacock (1961) reasoned that the increase in public sector spending does not increase or follow any smooth and continuous trend. According to Peacock (1961), an increase in public expenditure through time follows a stepwise fashion or occurs in sets of steps. They observed that citizens do not like to pay taxes, while the government is in a habit of spending more money, and resolved that the government should concentrate more on the wishes of their citizens. The Peacock and Wiseman theory is predicated on three major assumptions. The first being that the decision about public spending on various items is political and can be influenced using the ballot box or a media engineered by the citizens. Secondly, political choices as to the use of scarce resources pale in comparison with those operating in the market system. Thirdly, citizens can express suggestions on an acceptable level of public spending.

\section{Review of Empirical Literature}

Otto (2012), using secondary data, examined the nexus between national security and development in Nigeria for a period covering from 1980 to 2009. The study used the ordinary least square method of data analysis with national security measured using public security spending and development index using the gross domestic product (GDP). The outcome of their investigation revealed the presence of a positive relationship between security and development. It is therefore recommended that those who are in authority and claim to represent the people should listen and follow the aspiration of the wider majority including deepening democratic process and experiences.

Adopting the Autoregressive Distributed Lag (ARDL) estimation method, Akpan and Eweke (2018) employed secondary data sourced from the statistical bulletin of the Central Bank of Nigeria and other secondary sources, examined the impact of security spending and public debt on economic growth in Nigeria for a period extending from 1994 to 2016. The result of the bound test affirmed the existence of co-movement between security spending, public debt and real gross domestic product (an index of economic growth). The outcome of the ARDL estimation conducted revealed that increased levels of public debt and security spending accelerates real GDP both in the short run and long run. This prompted the paper to recommend 
that emphasis should be directed to internal security expenditure and domestic debt with the former be slashed greatly as compared to the latter.

Apanisile and Okunlola (2014) examines the effect of military expenditure on output in Nigeria both in the short-run and in the long run period. In addition, it verified whether military expenditure is an economically non-contributive activity using ARDL bound testing approach to cointegration. Results showed that military spending has negative and significant effects on output in the short-run but positive and significant effect in the long-run. Labour and capital have positive and significant effects both in the long-run and short-run, in addition labour has the highest co-efficient (3.0709) in the long run. The study therefore recommended that the government should reduce its expenditure on defence and concentrate more on human capital development, since military spending contributes nothing to output in the short run.

Fefa, J. (2014) examined the cost of insecurity on the Nigerian economy using times series data from 1986 - 2011. ADF tests conducted show the stationarity of the series at least at second difference with a probability of $99 \%$. A co-integration to show long-run relationship was then estimated using the Engle-Granger Test, which indicated that a long-run relationship existed among series. The Rho- 1 values indicate that the explanatory variables were strongly positively correlated with the dependent variable, except for FDI which had a weak relationship. The VCM estimates show that a long run positive relationship exists between GDP and the independent variables. The study found that an increase in DEXP, INSEXP (that is a reduction in insecurity) leading to an increase in FDI and GFCF would naturally cause GDP in Nigeria to increase and vice-versa. In other words, insecurity would exert a negative influence on GDP. The study therefore recommended that sincerity of purpose on the part of government through transparency and accountability, would reduce insecurity and the economy would grow.

Oriahki (2012) in their study investigated the impact of national security on foreign direct investment in Nigeria using the Least Square method. They observed that national security proxy by the defense and security vote (annual expenditure on security) crowd out foreign direct investment in Nigeria. Foreign direct investment, as we know, is a vital source of savings for any developing country and thus, an engine for growth; however, it is a paramount source of concern when the FDI is being crowded out and impacted negatively by issues of insecurity as it is the case of Nigeria. To provide solution, the study recommended that the government, the major player in security, should adopt strong policy measures by devising a more holistic approach to tackling the state of insecurity by entrenching the culture of transparency such that funds allocated to the sector (security) are effectively utilized for equipping the security system to meet the 21st century's standard. Also, it recommended that the government should seek technical assistance in the area of/ intelligence from advanced countries. Finally, the study was of the view that proactive measures be adopted by the government.

\section{Evaluation of Empirical Literature}

Otto and Nkpere (2012), Apamisile (2014), Oriahki (2012) and Akpan (2018) opine that it is clear that what was examined was how security affects Gross Domestic Product (GDP), Real Gross Domestic Product (RGDP), and Foreign Direct Investment (FDI). Having seen the foregoing studies, this paper tries to emphasize the implicating dangers of insecurity to the economic development of Nigeria, especially now that there is an increasing rate of insecurity in the face of seemingly government's inability to fight insecurity, and how it affects unemployment and inflation. This paper is, therefore, using the Misery Index as a measure of 
economic development in its study, which is the gap it tries to fill. And in doing so, it extends knowledge in the subject area.

\section{METHODOLOGY}

The paper adopted the Ex-post facto research method and time series data. The employed secondary data were sourced from the Central Bank of Nigeria (CBN) statistical bulletin and the World Development Indicator of World Bank covering a period of 38and spanning from 1981 - 2018. The model used builds on the work of Otto \& Ukpere (2012), with modification as a result of the use of misery index as a measure of economic development which is the dependent variable and the addition of Foreign Direct Investment (FDI) as part of the explanatory variables as well as the extension of the time frame. The paper adopted the error correction model (ECM) estimation technique. In order to ensure detailed analysis, the study undertook a descriptive analysis of the variables of the model, this was succeeded by the unit root test conducted using the Augmented Dickey-Fuller (ADF) test, followed by a cointegration test carried out using the bound test. The ECM technique was then employed, following the order of integration of the variables of the model, to estimate the short run behaviour of the variables.

\section{The Model Specification}

The model is stated in a functional form as;

$$
\mathrm{MI}=\mathrm{f}(\mathrm{CDEX}, \mathrm{RDEX}, \mathrm{FDI})
$$

This can be further stated as;

$M I=B_{0}+B_{1} C D E X+B_{2} R D E X+B_{3} F D I+U_{t}$

The log-linear variety of equation3.5A above is expressed as follows:

$$
\mathrm{InMI}_{\mathrm{t}}=\lambda_{0}+\lambda_{1} \mathrm{CDEXt}+\lambda_{2} \mathrm{RDEXt}+\lambda 3 \text { FDIt }+\mathrm{e}_{\mathrm{t}}
$$

where:

$\mathrm{MI}_{\mathrm{t}}=$ Misery Index at time $\mathrm{t}$ (an index of economic development)

$\mathrm{CDEX}_{\mathrm{t}}=$ Government Capital Defence Expenditure at time $\mathrm{t}$

$\mathrm{RDEX}_{\mathrm{t}}=$ Recurrent Defence Expenditure at time $\mathrm{t}$

$\mathrm{FDI}_{\mathrm{t}}=$ Foreign Direct Investment at time $\mathrm{t}$ (control variable)

$\lambda_{0}=$ constant term

$\lambda_{1}-\lambda_{3}=$ parameter estimates of the explanatory variables

In = Natural log transformation

et $=$ Random disturbance term 
In line with economic theories, government capital expenditure on defence (CDEX) and government recurrent expenditure on defence (RDEX) are expected to have a positive relationship with misery index, while foreign direct investment (FDI) is expected to have or exhibit a negative or inverse relationship with misery index.

The Equilibrium Correction Model (ECM) representation of the ARDL approach is as follows;

$$
\begin{aligned}
\Delta \operatorname{InMI}_{t}=\beta_{0} & +\sum_{i=1}^{m} \beta_{1} \Delta \operatorname{InMI}_{t-i}+\sum_{i=1}^{n} \beta_{2} \Delta \operatorname{InCDEX} X_{t-i}+\sum_{i=1}^{r} \beta_{3} \Delta \operatorname{InRDEX_{t-i}} \\
& +\sum_{i=1}^{s} \beta_{4} \Delta \operatorname{InFDI} I_{t-i}+w E C T_{t-1}+V_{t} \ldots \ldots \ldots \ldots \ldots \ldots \ldots \ldots(3)
\end{aligned}
$$

Where;

$\mathrm{m}, \mathrm{n}, \mathrm{r}$, and $\mathrm{s}=$ lag length for the variables of interest

$\Delta=$ first differencing operator

$\mathrm{V}_{\mathrm{t}}=$ white noise disturbance term

$\beta_{1}-\beta_{4}=$ short-run parameter estimates

$\beta_{0}=$ short-run intercept

$\mathrm{w}=$ coefficient of the error correction term

\section{RESULTS AND DISCUSSIONS}

Table 1 Descriptive Statistics of the Variables in the Model

\begin{tabular}{lllll}
\hline & MI & CDEX & RDEX & FDI \\
\hline Mean & 30.8607 & $6.68 \mathrm{E}+09$ & $7.04 \mathrm{E}+12$ & $2.70 \mathrm{E}+09$ \\
Median & 26.8450 & 4338.550 & 13369.00 & $1.73 \mathrm{E}+09$ \\
Maximum & 79.0400 & $1.31 \mathrm{E}+11$ & $2.66 \mathrm{E}+14$ & $8.84 \mathrm{E}+09$ \\
Minimum & 11.2200 & 18.5000 & 361.9235 & $1.89 \mathrm{E}+08$ \\
Std. Dev. & 16.224 & $2.36 \mathrm{E}+10$ & $4.32 \mathrm{E}+13$ & $2.57 \mathrm{E}+09$ \\
Skewness & 1.242 & 4.2523 & 5.9183 & 1.0676 \\
Kurtosis & 3.9463 & 21.7217 & 36.0267 & 2.9082 \\
& & & & \\
Jarque-Bera & 11.1952 & 669.4897 & 1948.880 & 7.2331 \\
Probability & 0.0037 & 0.0000 & 0.0000 & 0.0268 \\
Observations & 38 & 38 & 38 & 38 \\
\hline
\end{tabular}

Source: Own computation using E-Views 10 
The table above presents the central tendency statistics for each individual variable of the model as it gives summary statistics on variables mean, maximum and minimum values, standard deviation, skewness and kurtosis statistics. As made known from the table above, the average misery index (which is a combination of unemployment rate and inflation rate) for Nigeria for the duration of the study work which ran from 1981 to 2018 was 30.8607, with it hitting a maximum of 79.0400 and a minimum of 11.2200, and a standard deviation of 16.224. Government capital defence spending averaged 6.68E+09 during the 38 years of the study period, with the maximum capital defence spending being $1.31 \mathrm{E}+11$ and a minimum of N18.50 billion was spent on capital defence during the study period. As revealed by the table above, government recurrent spending on defence averaged a total of N7.04E+12 during the length of the study, hitting a maximum of $\mathrm{N} 2.66 \mathrm{E}+14$ and a minimum defence spending of $\mathrm{N} 361.9235$ million. The table suggests that the average foreign direct investment into the study for the 38 years which this study concentrated on was $\mathrm{N} 2.70 \mathrm{E}+09$, with the maximum foreign direct investment inflow of N8.84E+09 and a minimum of N1.89E+08. The result of the skewness indicates that all variables (MI, CDEX, RDEX and FDI) are positively skewed, implying that means and median of distribution of the series are greater than their mode. Results of the kurtosis revealed that the series foreign direct investment (FDI) is platykurtic, while series such as misery index (MI), government capital spending on defence (CDEX), and government recurrent spending on defence (RDEX) are leptokurtic. The probability values of the JarqueBera statistics for each of the series revealed that all considered series such as misery index (MI), government capital spending on defence (CDEX), government recurrent spending on defence (RDEX), and foreign direct investment (FDI) are normally distributed.

Table 2: Summary of ADF unit tests results

\begin{tabular}{llllll}
\hline Variables & Levels & $\begin{array}{l}\text { Critical } \\
\text { value (5\%) }\end{array}$ & $\mathbf{1}^{\text {st }}$ Diff. & $\begin{array}{l}\text { Critical } \\
\text { value (5\%) }\end{array}$ & $\begin{array}{l}\text { Order } \\
\text { Integration }\end{array}$ \\
\hline InMI & -0.3749 & -1.9501 & -7.1113 & -1.9506 & $\mathrm{I}(1)$ \\
InCDEX & 0.1738 & -2.9540 & -5.9154 & -2.9540 & $\mathrm{I}(1)$ \\
InRDEX & 1.5113 & -2.9571 & -4.7152 & -2.9571 & $\mathrm{I}(1)$ \\
InFDI & -1.7504 & -2.9434 & -10.8996 & -2.9458 & $\mathrm{I}(1)$ \\
\hline
\end{tabular}

Source: Author's computation from E-views 10

Annual variables or variables that flow through time usually possess the attributes of inherent shocks and lack of stability in them and for the avoidance of a spurious regression whereby a non-stationary variable is regressed on another or multivariate stationary variables, it is imperative to know for certain the stationarity of the variables. To achieve this, a unit root test was carried out and the study favoured the Augmented Dickey-Fuller (ADF) approach to stationarity test and determination of the order of integration of the variables that are captured in the models of the study.

The table above reports the outcome of the augmented Dickey-Fuller (ADF) test. The result of the test showed that none of the variables was stationary at level. This conclusion is based on 
the glaring empirical evidence that their respective ADF statistics at level was less than its corresponding critical value at 0.05 level of significance. The variables were then differenced once where the assumed stationarity. Conclusively, it can be said that the variables incorporated in the model were integrated of order one I(1), thus fulfilling the condition for the utilization of the Johansen co-integration test in testing for the presence of a possible long-run relationship among the variables in each individual model.

Table 3: Result of Johansen Co-integration Test

\begin{tabular}{cccc}
\hline Series: INMI INCDEX INRDEX INFDI & & \\
\hline Hypothesized & Trace & $\mathbf{0 . 0 5}$ & \\
No. of CE(s) & Statistics & Critical Value & Prob. ** \\
None $*$ & 66.53033 & 47.85613 & 0.0004 \\
At most 1 & 21.48416 & 29.79707 & 0.3281 \\
At most 2 & 9.489172 & 15.49471 & 0.3221 \\
At most 3 & 0.663126 & 3.841468 & 0.4155 \\
Hypothesized & Max-Eigen & $\mathbf{0 . 0 5}$ & \\
No. of CE(s) & Statistic & Critical Value & Prob. ** \\
None $*$ & 45.04618 & 27.58434 & 0.0001 \\
At most 1 & 11.99498 & 21.13162 & 0.5482 \\
At most 2 & 8.826046 & 14.26460 & 0.3009 \\
At most 3 & 0.663126 & 3.841466 & 0.4155 \\
\hline
\end{tabular}

Source: Author's Computation using EViews 10

The table above documented the outcome of the Johansen co-integration test conducted. The test of long run relationship upon which the Johansen cointegration test was adopted is based on two tests, namely the Trace Test and Max-Eigen Test.

The trace test co-integration analysis result shows that there is at least one (1) co integrating equation in the model. The trace statistic for no co-integration was rejected as shown by the probability value. Maximum Eigen value statistic shows that there exist one (1) co-integration equation in the model. In all, both the trace and maximum Eigen value statistic show the existence of one (1) co-integration equation. Thus, there is a fixed long run relationship among the variables. This implies that the long run relationship can be modelled and estimated. It also implies the existence of long run relationship between misery index (MI), government capital spending on defence (CDEX), government recurrent spending on defence (RDEX), and foreign direct investment (FDI). Hence, the analysis proceeded to the estimation of the error correction model which is the short run adjustment mechanism.

With the establishment of common drift between the variables in the long run or that they move together in the long term, the error correction model can be estimated to examine the dynamics of the variables. 
Table 4: Result of Normalized Cointegration Coefficients

\begin{tabular}{|c|c|c|c|}
\hline $\begin{array}{l}\text { Cointegrating } \\
\text { Equations(s): }\end{array}$ & \multicolumn{2}{|c|}{ Log likelihood } & -169.5476 \\
\hline \multicolumn{4}{|c|}{$\begin{array}{l}\text { Normalized cointegrating coefficients (Standard error in parentheses) [t statistics in } \\
\text { brackets] }\end{array}$} \\
\hline InMI & $\operatorname{InCDEX}$ & $\operatorname{InRDEX}$ & $\operatorname{InFDI}$ \\
\hline \multirow[t]{3}{*}{1.000000} & 6.6838 & -5.0589 & -8.5653 \\
\hline & $(0.8748)$ & $(0.7132)$ & $(1.2210)$ \\
\hline & [7.6403] & {$[-7.0932]$} & [-7.0149] \\
\hline \\
\hline \multicolumn{4}{|c|}{$\begin{array}{c}\text { Adjustment Coefficients (standard error in parentheses) } \\
\qquad \begin{array}{c}\text { (InMI) } \\
0.0072 \\
(0.0199)\end{array}\end{array}$} \\
\hline$D(\operatorname{InCDEX})$ & $\begin{array}{l}-0.5631 \\
(0.1734)\end{array}$ & & \\
\hline$D(\operatorname{InRDEX})$ & $\begin{array}{l}-0.4123 \\
(0.2398)\end{array}$ & & \\
\hline$D(\operatorname{InFDI})$ & $\begin{array}{c}-0.0394 \\
(0.01671)\end{array}$ & & \\
\hline
\end{tabular}

Source: Author's Computation using EViews 10

The table above reports the result of the normalized cointegration equation following the confirmation of co-movement between the variables of interest established by means of the Johansen cointegration test. In providing explanation or interpreting the above results, opposite signs are utilized. From table 4, In CDEX exhibit a negative relationship between misery index in the long run and the inverse relationship is significant as established by the corresponding tstatistics which is above 2. This implies that an increase in capital defence expenditure results in a decrease in both unemployment and inflation level in the long run. Conversely, results from the normalized cointegration revealed the existence of direct and significant relationship between recurrent defence expenditure and misery index as the latter moves in the same direction as variations in recurrent capital expenditure. In a similar vein, a positive and significant relationship was revealed to exist between FDI and misery index in the long run.

\section{Error/Equilibrium Correction Model}

As posited by Brooks (2019), the estimation of the equilibrium correction model affords one to assess the short run dynamics of the variables incorporated in the model and the speed at which the model adjusts to long run equilibrium following short run impulses. The reparameterized error correction model is presented in the table below;

\section{Table 5: Parsimonious ECM Result}

Dependent variable: $D\left(\operatorname{InM} I_{t}\right)$

\begin{tabular}{ccc}
\hline Variable & Coefficient & Prob. \\
\hline$D\left(\operatorname{InM} I_{t-1}\right)$ & 0.5036 & 0.0058 \\
$D\left(\operatorname{InC} C E X_{t}\right)$ & 0.0418 & 0.3637 \\
$D\left(\operatorname{InC} C E X_{t-2}\right)$ & 0.0150 & 0.8111 \\
\hline
\end{tabular}




\begin{tabular}{ccc}
\hline$D\left(\operatorname{InRDE} X_{t}\right)$ & -0.0302 & 0.4254 \\
$D\left(\operatorname{InRDEX}_{t-1}\right)$ & -0.0109 & 0.4860 \\
$D\left(\operatorname{InRDE} X_{t-2}\right)$ & -0.0127 & 0.7246 \\
$D\left(\operatorname{InFDI}_{t-1}\right)$ & -0.1547 & 0.2574 \\
$E C M_{t-1}$ & -0.7017 & 0.0003 \\
$C$ & 0.0004 & 0.9951 \\
\hline
\end{tabular}

R-squared $=0.45 \quad$ Prob. $($ F-Stat $)=0.0264 \quad$ Durbin-Watson stat $=1.59$

Source: Own Computation using Eviews 10

The result of table 5 above speaks on the short run behaviour of the variables and their associated relationship with the regress and geared towards examining the how long it takes for the model to achieve the economic goal of long run equilibrium following distortions from the explanatory variables witnessed in the short term. The result documented above revealed that lag one (1) of misery index exert a positive and significant impact on the current level of misery index in Nigeria. As observed from the table above, a percentage increase in previous year's level of misery index results in a 0.5036 per cent increase in current level of misery index. The relationship between current level of government capital expenditure on defence and economic development (index using misery index) in Nigeria is positive but statistically insignificant as the probability value is above the 0.05 level of significance. An increase in government capital spending on defence raises the misery index level by 0.0418 percentage. The current influence of government recurrent spending on defence on current level misery index in Nigeria is negative as an increase in government recurrent spending on defence by one per cent causes current level misery index to drop by 0.030 per cent, although this impact is insignificant. In the short term, the behaviour of one lag of foreign direct investment on misery index is negative, conforming to the prior expectation, as one percent increase in current level of foreign direct investment causes the misery index level to nosedive, however its impact is insignificant. The coefficient of the lagged error correction term (ECT) of -0.70, which fulfils the conditions of being negative and significant at 0.05 level of significance indicating that the model converges to long run equilibrium at a speed of 70 percent. This implies that about 70 per cent of the disequilibrium witnessed in the short run and produced by fluctuations that emanated from the regressors will be corrected before the end of the next period and the dissemination of the residual will take less than 7 months. This attests to the fast-equilibrating speed of the model.

\section{Diagnostic Test}

Table 6 Diagnostic Report for Parsimonious ECM

\begin{tabular}{lllll}
\hline $\begin{array}{l}\text { Test/Hypothesis Tested (hypothesis is in } \\
\text { null form) }\end{array}$ & Test type & $\begin{array}{l}\text { Test- } \\
\text { stats. }\end{array}$ & Prob. & Decision \\
\hline $\begin{array}{l}\text { Residual Normality } \\
\text { (Residuals are Normally Distributed) }\end{array}$ & Jarque-Bera & 1.0075 & 0.6042 & Accept \\
$\begin{array}{l}\text { Serial Correlation } \\
\text { (there is no serial correlation) }\end{array}$ & $\begin{array}{l}\text { Breusch-Godfrey LM } \\
\text { Test }\end{array}$ & 4.8267 & 0.0895 & Accept \\
$\begin{array}{l}\text { Heteroskedasticity } \\
\text { (there is Homoskedasticity) }\end{array}$ & ARCH & 2.3402 & 0.3103 & Accept \\
\hline
\end{tabular}

Source: Own computation using E-Views 10 
In addition to the prior test conducted, the study also undertook a diagnostic test on the error correction model (ECM) to ensure that the parameter estimates can be utilized for future prediction or forecast. The diagnostic tests conducted include the test of normality for which the Jarque-Bera statistics or test was used, serial correlation test employed to ascertain if correlation exists between the current and lagged estimates of the error term for which the Breusch-Godfrey LM test was favoured, the test for constant variance or homoskedasticity test for which the ARCH test. From the table above, the error term is normally distributed as the probability value of the Jarque-Bera statistics exceeds the 5 percent level of significance. The Breusch-Godfrey LM test showed absence of serial correlation between current and lagged values of the error term, as the $\mathrm{ARCH}$ test revealed the existence of constant variance, suggesting the presence of homoscedasticity.

\section{CONCLUSION AND POLICY IMPLICATIONS}

The import of this paper was to examine the effect of national security on the economic development of the Nigerian State using annual time series data obtained from the statistical bulletin of the Central Bank of Nigeria and the World Development Indicator as provided by the World Bank, with the investigation covering a period of 38 years starting from 1981 and eclipsing in 2018. The product of the long run autoregressive distributed lag (ARDL) method of estimation used divulged that increase in government capital spending on defence diverts the national resources that would have been plunged into the development of the State as the misery index increases with increase in the said spending. However, the impact on misery index during the length of the study was insignificant. On the other hand, a negative and insignificant relationship was found to exist between government recurrent spending on defence and misery index resulting in the verdict or conclusion that national security does impact on economic development in Nigeria. On the backdrop of this, the following recommendations were proposed;

1. Insecurity has been judged as debilitating to economic development in developing countries. Owing to the importance of a secured ambience to economic development, the study proposed that the Federal Government of Nigeria re-assesses the content and composition of her defence spending to make it development oriented.

2. The revelation of the empirical analysis points to the fact that previous year's misery index impacts significantly on current year's misery index. The study advanced that the government of Nigeria engineer workable policies to address the current level of unemployment and inflation. One of such policies should be toward the promotion of the agrarian economy.

3. Embezzlement and diversion of the public fund has been the bane of the Nigerian State and this has resulted in the lack of utilization of the allocated fund for the purpose for which it was intended. The study recommends that a committee be set up to monitor the disbursement of defence expenditure and subsequent utilization so as to ensure judicious employment of the fund in the fight against the security challenges bedevilling the Nigeria State. 
4. Wipe out greed and extreme selfishness among the political class in government. This is because if a country is established from relations from different groups, it will continue to exist if the relations remain fair and the ideals that keep it alive remain on balance and valid to all parts. If not so, the country will collapse or at best breeds insecurity.

\section{REFERENCES}

Adam, R. H. (2009). Security: A vital factor of development. Oxford University Press. Akpan, E. S., \& Eweke, G. O. (2018). Security spending and public sector debt: Implication on Nigeria's economy. Euro Economica, 37(3), 180-190.

Akpakpan, D.E. (1987). Crossroads in Nigerian development and changes. New Generation Publishers.

Apanisile, O.T., and Okunlola, O.C. (2014). Does military expenditure influence economic growth in Nigeria during 1989 - 2013? A bound test approach. Romanian Journal of Fiscal Policy, 5, 2(9); 56 - 71.

Barton, G. (2019). National security is too important to be left abandoned to the politics of fear. The conversation Africa.

Beijer, M. (2010). Economic and social rights and the prospects of conflict prevention and peace Building in Africa. J.A.L. 47.

Bello, F. (2017) "Public policy implication on national security. June, 4, 2017. http://www.nialsnigeria.org/pub/.p.4.

Claudia, A. (2010). Parameters of Nigeria's defence policy in national interest. National Security and Defence Policy Revisited, Minna, Tradoc, 311-324

Fefa, J., \& Irefin, D. (2014). The Cost of insecurity on emerging economies: The Nigerian experience. America Academic and Scholarly Research Journal, 6(2).

Imobighe, T.A.(2001). "An overview of the theoretical issues in African security" in R. Akindela, and B. Ate (eds), beyond conflict resolution: Managing African security in the $21^{\text {st }}$ century. Vintage publisher.

Mesjaz, C. (2004). "Security as an analytical concept". A paper presented at the $5^{\text {th }}$ PanEuropean Conference on International Relations Held at Hague September 9 - 11, 2004.

Nwohie (2011)."Nigeria's defence policy. A critique of the fundamental thoughts for progressive military power building and defence policy transformation" in Mbache, $Q$ and Sokoto (eds). Nigeria defence and national security: Policies and strategies Kaduna. Meclusa Academic Publisher Limited.

Obasi, C. N., Asogwa, F. O., \&Nwafee, F. I. (2018). Military expenditure and human capital development in Nigeria. American Journal of Economics, 8(5), 221-229.

Onovo, O. (2009). "Combating the crime of armed robbery and kidnapping in the South East and South-South zones of Nigeria: Strategies, challenges and prospects". Igbinedion Journal of Diplomacy and Strategies. Vol. 1, no. 1

Oshio, E. (2009). The challenge of national security and development. Being a paper delivered at the Delta State Christian professional league seminar on crisis management and Nation building at Grand Hotel, Asaba, on Thursday, 19th November.

Otto, G., \&Ukpere, W. I. (2012).National security and development in Nigeria. African Journal of Business Management, 6(23), 6765-6770. 
Pesaran, M. H., Shin, Y., \& Smith, R. J. (2001). bounds testing approaches to the analysis of level relationships. Journal of Applied Econometrics, 16(3), 289-326.

Todaro, M. and Smith, S. (2011). Economic development. Persons Education.

WhatisMiseryIndex

https://www.proshareng.com/news/nigeriainlestopedia.om/terms/n/merseryindex. asp.

Wilson, G. (2017). Development economics: A concise Text. Pearl Publishers.

Yero, H.I (2010). Rural development as a tool for sustainable development in Ghana in re engineering the fight against corruption $3^{\text {rd }}$ UAAC. International Bi-Lingual Conference on Research as Development.

Zabachi, I. (2011) Nigerian defence and security environment" in Mbachu, O. and Sokoto (eds). Nigeria defence and national security: Policies and strategies. Medusa Academic Publishers Limited.

Zingel, W.P. (2010). National security and economic development: Securing development developing security.: Oxford University Press. 